\title{
Manajemen usaha Ayam Pedaging Jantan dan Betina dengan Penambahan Suplemen Organik Cair
}

\section{Management of Male and Female Broilers with Addition of Liquid Organic Supplements}

\author{
Kamaludin $^{1}$, P W Dzikrillah, M F Azhoheru ${ }^{1}$, Suhendrian ${ }^{1}$, W Hardiansyah $^{1}$, D D Putri ${ }^{1}$, dan \\ G G Maradon ${ }^{*}$ \\ ${ }^{1}$ Jurusan Peternakan Politeknik Negeri Lampung, \\ Jln. Soekarno Hatta No 10 Rajabasa Bandar Lampung, 35144 \\ *E-mail korspondensi: gusma@polinela.ac.id
}

\begin{abstract}
This study aims to determine the growth of broiler chickens and analyze the feasibility of broiler farming with the addition of liquid organic supplements. Liquid organic supplements (SOC) or also called probiotics contain Lactobacillus sp, Azetobacter sp, Basiluss sp, vitamins, and minerals. SOC can increase antibodies, reduce stress levels, suppress the onset of disease, help stimulate appetite, and accelerate the growth of broiler chicken. Broilers are divided into 4 treatments female broilers without SOC, male broilers without SOC, female broilers with the addition of SOC, and treatment of male broilers with the addition of SOC. Based on the results and discussion the highest PBB is obtained by male chicken with SOC. Feasibility analysis shows that all treatments are feasible, B/C (3.11) and $R / C$ (3.18) values of treatments added by SOC are higher than treatments without SOC.
\end{abstract}

Keywords: Broiler, Feasibility Analysis, SOC

Diterima: $\quad$ Disetujui:

\section{PENDAHULUAN}

Pada pemeliharaan ayam pedaging kemampuan ayam betina dalam mengkonversi makanan menjadi daging tidaklah sebagus ayam jantan, selain itu ayam betina lebih rentan terhadap penyakit dibandingkan ayam jantan (Ozkan et al., 2010). Quintiro Filho et al (2010) melaporkan bahwa perbedaan ayam pedaging memengaruhi konsumsi pakan, bobot badan akhir, dan FCR, sehingga mengakibatkan produktivitas ayam jantan lebih tinggi dibandingkan ayam betina (Qurniawan Anas et al., 2016).

Pada industri ayam pedaging, harga day old chik (DOC) jantan lebih tinggi. Pemberian suplemen organik cair yang merupakan suplemen khusus ternak. Suplemen organik cair di sebut juga dengan probiotik karena terdapat Laktobasillus sp, Azetobacter sp, Basiluss sp dan kandungan lainya yaitu : kandungan mineral - mineral yang penting pertumbuhan tulang organ luar dan dalam, pembentukan darah dan lain-lain. Asam-asam amino utama seperti arginin, histadin, isoleucine, lycine, methionine, thryptophan, dan valine sebagai penyusun protein untuk pembentukan sel, jaringan, dan organ tubuh. Vitamin-vitamin lengkap yaitu A, D, E, K, C dan B komplek untuk kesehatan dan ketahanan tubuh. Pada umumnya dilakukan dengan menambahkan pada bahan pakan dan air minum pada berbagai hewan ternak. 
Suplemen organik cair di sebut juga dengan probiotik karena terdapat Laktobasillus sp, Azetobacter $s p$, Basiluss $s p$ dan kandungan lainya yaitu : kandungan mineral - mineral yang penting pertumbuhan tulang organ luar dan dalam, pembentukan darah dan lain-lain. Asam-asam amino utama seperti arginin, histadin, isoleucine, lycine, methionine, thryptophan, dan valine sebagai penyusun protein untuk pembentukan sel, jaringan, dan organ tubuh. Vitamin-vitamin lengkap yaitu A, D, E, K, C dan B komplek untuk kesehatan dan ketahanan tubuh. Kandungan yang terdapat dalam suplemen organik cair seperti yang disebutkan menjadikan bahan ini sangat direkomendasikan sebagai bahan tambahan pada pakan hewan ternak (HCS, 2016).

\section{MATERI DAN METODE}

Penelitian ini menggunakan DOC (day old chick) CP-707 berjumlah 200 ekor. SOC yang berasal dari perusahaan PT Hidup Cerah Sejahtera. Pakan yang digunakan adalah pakan komersil untuk ayam broiler yaitu BR-1 dari PT Comfeed. Alat yang digunakan antara lain kandang panggung, timbangan, tempat pakan, dan tempat minum.

Penelitian ini menggunakan 4 perlakuan dengan perlakuannya antara lain: ayam betina tanpa pemberian suplemen organik cair; ayam jantan tanpa pemberian suplemen organik cair; ayam betina dengan pemberian suplemen organik cair; dan ayam jantan dengan pemberian suplemen organik cair. Pengamatan yang dilakukan antara lain performa produksi (meliputi pertambahan bobot badan, konsumsi pakan, Feed Consumption Rasio (FCR) dan mortalitas) dan analisis biaya (Biaya Produksi, Break Event Point (BEP), $\mathrm{R} / \mathrm{C}$, dan $\mathrm{B} / \mathrm{C})$.

\section{HASIL DAN PEMBAHASAN}

Berdasarkan hasil pengamatan terhadap produksi ayam broiler selama 4 minggu pemeliharaan dapat disajikan pada tabel 1.

Tabel 1. Produktivitas ayam pedaging selama 4 minggu

\begin{tabular}{lcccc}
\hline Peubah & $\begin{array}{c}\text { ayam betina } \\
\text { tanpa SOC }\end{array}$ & $\begin{array}{c}\text { ayam jantan } \\
\text { tanpa SOC }\end{array}$ & $\begin{array}{c}\text { ayam betina dengan } \\
\text { penambahan SOC }\end{array}$ & $\begin{array}{c}\text { ayam betina dengan } \\
\text { penambahan SOC }\end{array}$ \\
\hline $\begin{array}{l}\text { Konsumsi pakan } \\
\text { (gr/ekor) }\end{array}$ & 1938 & 1950 & 1949 & 1950 \\
PBB (gr/ekor) & 1305 & 1326 & 1324 & 1331 \\
FCR & 1,485 & 1,471 & 1,472 & 1,465 \\
Mortalitas $\%$ & $4 \%$ & $2 \%$ & $0 \%$ & $0 \%$ \\
\hline
\end{tabular}

Konsumsi pakan merupakan jumlah pakan yang dimakan dalam jangka waktu tertentu. Pakan yang dikonsumsi ternak digunakan untuk memenuhi kebutuhan energi dan zat nutrisi lain. Konsumsi pakan tiap ekor ternak berbeda-beda. Konsumsi diperhitungkan sebagai jumah makanan yang dimakan oleh ternak. Konsumsi pakan (gram) dapat dilihat di Tabel 3. Hasil menunjukkan bahwa perlakuan konsumsi pakan terlihat bahwa pengaruh perlakuan pemberian suplemen organik cair terhadap konsumsi pakan selama pemeliharaan 4 minggu menunjukan angka yang berbeda, konsumsi pakan kelompok ayam betina tanpa SOC (P1) yaitu 1938 gram/ekor, kelompok ayam pejantan tanpa SOC (P2) ransum yang terkonsumsi yaitu 1950 gram/ekor, kelompok ayam betina dengan penambahan SOC (P3) menghabiskan ransum gram/ekor 1949 dan kelompok ayam pejantan dengan penambahan SOC (P4) sebesar 1950 gram/ekor. Konsumsi pakan P4 dan P2 memiliki kesamaan pada konsumsi pakan sebesar 1950 gram/ekor, sedangkan P3 1949 gram/ekor lebih tinggi dari P1 1938 gram/ekor. Hal ini diduga karena pemberian suplemen organik cair (probiotik) kedalam air minum mampu meningkatkan konsumsi pakan. Hal ini sesuai dengan pendapat Borrow (1992) yang menyatakan bahwa secara umum manfaat penambahan probiotik adalah membantu 


\section{Kamaludin dkk : Pertumbuhan Ayam Pedaging Jantan dan Betina dengan Penambahan Suplemen Organik}

Cair/Peterpan 1(1):21-25

sistem pencernaan unggas. Konsumsi pakan dipengaruhi oleh faktor seperti besar ukuran tubuh, keaktifan (jantan lebih aktif dibandingkan betina), temperatur, kualitas dan kuantitas pakan yang diberikan.

Pertumbuhan adalah suatu proses peningkatan ukuran tulang, otot, organ dalam dan bagian tubuh yang terjadi sebelum lahir (prenatal) dan setelah lahir (postnatal) sampai mencapai dewasa. Faktor yang mempengaruhi pertumbuhan adalah galur ayam, jenis kelamin, dan faktor lingkungan. Salah satu kriteria untuk mengukur pertumbuhan adalah dengan mengukur pertambahan bobot badan. Pertambahan bobot badan merupakan kenaikan bobot badan yang dicapai oleh seekor ternak selama periode tertentu. Pertambahan bobot badan pada pemeliharaan ayam pedaging jantan yang diberikan SOC pada air minum menghasilkan PBB sebesar 1331 gram/ekor. Sedangkan PBB jantan yang tidak diberikan SOC yaitu sebesar 1326 gram/ekor. Pertambahan bobot badan pada pemeliharaan ayam pedaging betina yang diberikan SOC pada air minum sebesar 1324 gram/ekor, sedangkan pada ayam pedaging betina tanpa SOC sebesar 1305 gram/ekor.

Nilai konversi pakan dipengaruhi oleh beberapa faktor antara lain genetik, tipe pakan yang digunakan, feed additive yang digunakan dalam pakan, manajemen pemeliharaan, dan suhu lingkungan (James, 2004). Jumlah pakan yang digunakan mempengaruhi perhitungan konversi ransum atau Feed Converstion Ratio (FCR). FCR merupakan perbandingan antara jumlah ransum yang dikonsumsi dengan pertumbuhan berat badan. Angka konversi ransum yang kecil berarti jumlah ransum yang digunakan untuk menghasilkan satu kilogram daging semakin sedikit (Edjeng dan Kartasudjana, 2006). Semakin tinggi konversi ransum berarti semakin boros ransum yang digunakan (Fadilah et al., 2007). Berdasarkan data pada tabel 3 Konversi perlakuan P4 dapat dilihat bahwa pemeliharaan jantan pemberian SOC menghasilkan FCR 1,47. Konversi Pakan perlakuan P2 pemeliharan ayam pedaging jantan tanpa pemberian SOC menghasilkan FCR 1,471. Konversi ransum pada perlakuan P1 ayam betina tanpa pemberian SOC sebesar 1,49, sedangkan pada perlakuan P3 ayam pedaging betina dengan pemberian SOC angka FCR diperoleh sebesar 1,47 dengan PBB gram/ekor.

Mortalitas atau kematian adalah salah satu faktor yang dapat mempengaruhi keberhasilan usaha pengembangan peternakan ayam. Angka mortalitas diperoleh dari perbandingan jumlah ayam yang mati dengan jumlah ayam yang dipelihara. Tingkat mortalitas dipengaruhi oleh beberapa fakor, diantaranya bobot badan, bangsa, tipe ayam, iklim, kebersihan lingkungan, sanitasi peralatan dan kandang serta penyakit (North dan Bell, 1990).

Berdasarkan hasil pada tabel 3 dapat dilihat bahwa tingkat mortalitas pada perlakuan yang diberikan SOC lebih baik. Hal ini disebabkan oleh kandungan SOC yang dapat meningkatkan efek baik untuk kesehatan, karena kandungan dalam suplemen organik cair terdapat probiotik yang dapat membantu pertumbuhan ayam pedaging dan meningkatkan kesehatan ternak, juga vitamin dan mineral yang memiliki manfaat penting dalam pertumbuhan ayam pedaging. Pada perlakuan P2 ayam mengalami kematian dikarenakan ayam terjepit pada sela litter. Pada perlakuan P1 ayam yang dipelihara mengalami kematian karena nafsu makan penurunan antibodi yang terus menurun selama 3 hari pada minggu keempat yang menyebabkan tidak terpenuhinya kebutuhan nutrisi dan ayam mengalami kematian. Hal ini sesuai dengan pendapat Sandholm dan Saarela (2003), Lactobacillus sp merupakan salah satu strain bakteri yang memenuhi syarat sebagai probiotik. Lactobacillus sp jika dikonsumsikan dengan jumlah cukup dapat menyebabkan efek baik dalam kesehatan ternak.

Angka kematian merupakan salah satu faktor yang dapat mempengruhi keberhasilan usaha ayam pedaging. Pemeliharaan ayam pedaging dinyatakan berhasil jika angka kematian secara keseluruhan kurang dari 5\% (North dan Bell, 1990). Pemeliharaan broiler dengan SOC menghasilkan mortalitas yang sangat baik yaitu sebesar 0\% karena SOC mengandung probiotik yang baik untuk pencernaan, serta vitamin dan mineral 


\section{Jurnal Peternakan Terapan}

yang dibutuhkan oleh ternak untuk meningkatkan daya tahan tubuh ternak terhadap penyakit. Hasil analisis biaya pemberian SOC pada ayam broiler disajikan pada Tabel 2.

Tabel 2. Analisis Biaya pemberian SOC pada broiler

\begin{tabular}{lcccc}
\hline Uraian & $\begin{array}{c}\text { ayam betina } \\
\text { tanpa SOC }\end{array}$ & $\begin{array}{c}\text { ayam jantan } \\
\text { tanpa SOC }\end{array}$ & $\begin{array}{c}\text { ayam betina dengan } \\
\text { penambahan SOC }\end{array}$ & $\begin{array}{c}\text { ayam betina dengan } \\
\text { penambahan SOC }\end{array}$ \\
\hline Jumlah ayam (ekor) & 50 & 50 & 50 & 50 \\
HPP (Rp) & 23,921 & 24,148 & 24,209 & 24,217 \\
harga jual (Rp) & 32,000 & 32,000 & 32,000 & 32,000 \\
Penerimaan (Rp) & $1,536,000$ & $1,568,000$ & $1,600,000$ & $1,600,000$ \\
BEP produksi & 37 & 38 & 38 & 38 \\
BEP jual (Rp) & 23,921 & 24,148 & 24,209 & 24,217 \\
Pendapatan (Rp) & 339,942 & 360,618 & 389,558 & 389,160 \\
R/C & 1.28 & 1.30 & 1.32 & 1.32 \\
B/C & 0.28 & 0.30 & 0.32 & 0.32 \\
\hline
\end{tabular}

Analisa usaha adalah proses perhitungan tentang besarnnya seluruh biaya (pengeluaran) yang diperlukan dalam suatu proses produksi dan penerimaan yang akan dan diperoleh dari produksi yang dapat dihasilkan dari usaha (Suprati, 2005). Break Even point atau BEP adalah suatu analisis untuk menentukan dan mencari jumlah barang atau jasa yang harus dijual kepada konsumen pada harga tertentu untuk menutupi biaya-biaya yang timbul serta mendapatkan keuntungan. BEP Produksi < produksi ayam menunjukkan bahwa usaha ini menguntungkan. Analisis kelayakan usaha R/C disajikan pada tabel 5. R/C pada proyek mandiri ini menunjukan hasil $>1$, sehingga usaha ini layak untuk dilanjutkan. Analisis kelayakan usaha B/C disajikan pada tabel 5. B/C pada proyek mandiri ini menunjukan hasil $>0$, sehingga usaha ini layak untuk dilanjutkan.

\section{KESIMPULAN}

Berdasarkan hasil dan pembahasan dapat disimpulan bahwa selama pemeliharaan ayam pedaging dengan penambahan SOC dihasilkan PBB yang baik pada kelompok ayam pedaging dengan penambahan SOC dibandingkan kelompok ayam yang tidak diberikan SOC. Analisis usaha menunjukan hasil bahwa usaha ini layak untuk dilanjutkan.

\section{DAFTAR PUSTAKA}

Edjeng S. \& Kartasudjana, R. 2006. Manajemen Ternak Unggas. Penebar Swadaya, Jakarta.

James, R. G. 2004. Modern Livestock and Poultry Production. $7^{\text {th }}$ Edition. Thomson Delmar Learning Inc., FFA Activities, London.

Kartasudjana, R. 2005. Manajemen Ternak Unggas. Fakultas Peternakan. Universitas Padjajaran Press, Bandung.

North, M. O. \& Bell, DD. 1990. Commercial Chicken Production Manual. $4^{\text {th }}$ Ed.the Avi Publishing Company Inc. Wesport, Connecticut.

Ozkan S., Takma C., Yahav S., Sogut B., Turkmut L., Erturun H., \& Cahaner A. 2010. The effects of feed restriction and ambient temperature on growth and ascites mortality of broilers reared at high altitude. Poult Sci 89(5): 974-985. doi:10.3382/ps.2009-00293

PT. HCS. 2015. SOC HCS Untuk Ternak Ayam -- Meningkatkan Bobot Ayam Boiler. 8 september 2018. Http://programhcs.com/soc-hcs-untuk-ternak-ayam-boiler/ 
Quinteiro-Filho WM, Ribeiro, A., Ferraz-de-Paula, V., Pinheiro, M.L., Sakai, M., Sa, L.R.M., Ferreira, A.J.P., \& Palermo-Neto, J. 2010. Heat stress impairs performance parameters, induces intestinal injury, and decreases macrophage activity in broiler chickens. Poult Sci 89(9): 1905-1914. doi:10.3382/ps.2010-00812

Qurniawan Anas, A. I. (2016). performans produksi ayam pedaging pada lingkungan pemeliharaan dengan ketinggian yang berbeda di sulawesi selatan. Jurnal Veteriner, 17.

Sandholm, T.M. \& Saarela, M., 2003. Functional Dairy Products. CRC Press, Woodhead Publishing Limited, Cambrige, England. pp. 78-90

Suprati, L. 2005.Teknologi Pengolahan Pangan Tepung Tapioka Dan Pemanfaatannya. PT Gramedia:Jakarta.80hlm. 